\title{
Article \\ Indoor and Outdoor Performance of an Enhanced Photovoltaic Panel through Graphene/Fins/Phase Change Materials
}

\author{
Daniele Colarossi * ${ }^{(1)}$ and Paolo Principi \\ Department of Industrial Engineering and Mathematical Sciences, Università Politecnica delle Marche, Via Brecce \\ Bianche 12, 60131 Ancona, Italy; p.principi@univpm.it \\ * Correspondence: d.colarossi@pm.univpm.it
}

\begin{abstract}
The operative temperature of a photovoltaic cell influences the electric conversion yield. This can be enhanced by cooling the panel. Among the studied solutions, phase change materials (PCM) exploit latent heat and absorb a large amount of energy at a nearly constant temperature. PCMs suffer from a low thermal conductivity. Under these premises the paper presents a hybrid graphene/fins/PCM cooling system to maximize efficiency gains and thermal recovery. An indoor laboratory characterization, under a solar simulator, compares the proposed model with a reference one (an identical, simple PV module) under fixed environmental conditions. Outdoor tests investigate the performances of the two systems under natural conditions. Indoor results show that the front temperature of the proposed PCM integrated module is averagely $6{ }^{\circ} \mathrm{C}$ less, with a peak of $8{ }^{\circ} \mathrm{C}$, than the reference case. This means an increase in the electric yield of about $3 \%$. Outdoor investigations prove that, when the PCM is solid and during the melting phase, the proposed system is averagely $1.12{ }^{\circ} \mathrm{C}$ and $4.87^{\circ} \mathrm{C}$ colder than the reference case, respectively. The thermal efficiency is $30 \%$ and $65 \%$, respectively. Once the melting process is completed, the performance becomes worse, and the hybrid panel is almost $3{ }^{\circ} \mathrm{C}$ warmer than the simple panel.
\end{abstract}

Citation: Colarossi, D.; Principi, P. Indoor and Outdoor Performance of an Enhanced Photovoltaic Panel through Graphene/Fins/Phase Change Materials. Appl. Sci. 2021, 11, 8807. https://doi.org/10.3390/ app11198807

Academic Editor: Asterios Bakolas

Received: 26 August 2021

Accepted: 16 September 2021

Published: 22 September 2021

Publisher's Note: MDPI stays neutral with regard to jurisdictional claims in published maps and institutional affiliations.

Copyright: (c) 2021 by the authors. Licensee MDPI, Basel, Switzerland. This article is an open access article distributed under the terms and conditions of the Creative Commons Attribution (CC BY) license (https:/ / creativecommons.org/licenses/by/ $4.0 /)$.
Keywords: phase change material; thermal storage; photovoltaic; nanoparticles; graphene; solar simulator; solar radiation

\section{Introduction}

The exploitation of solar radiation is fundamental for the transition from a fossil fuels-based technology to renewable ones. A photovoltaic (PV) panel allows a clean energy production transforming the radiation incident into electricity [1,2]. Nowadays, typical commercial PV panels, composed of silicon, have a photovoltaic conversion efficiency ranging from $15 \%$ to $20 \%$. Modern OPV (organic photovoltaic) modules can reach a higher performance $[3,4]$. The remaining share of energy is lost in the environment as heat. In addition, the just-defined yield refers to the standard test conditions (STC), namely, an incident radiation of $1000 \mathrm{~W} / \mathrm{m}^{2}$, an air mass of 1.5 and a cell temperature of $25^{\circ} \mathrm{C}$. This latter parameter is very influential because as the temperature increases, the efficiency decreases [5]. Quantitatively, it depends on the typology of the panel, for instance, for the prevalent mono crystalline-type, a power reduction of $0.5 \% /{ }^{\circ} \mathrm{C}$ has been observed. As a result, in warm periods and climates, the yield, which is already low under standard test conditions, can be significantly reduced. Accordingly, it is important to maintain the operating temperature as low as possible to maximize the efficiency of the module.

Over the years several strategies have been adopted to limit this phenomenon, with the aim of cooling the module. A macro subdivision can be an active and passive system [6,7]. An example of a passive system is natural air circulation. The main advantage is the low cost and lack of maintenance. On the other hand, they suffer from a low heat transfer rate, a low thermal conductivity and heat capacity of air, a dependence on wind direction and speed and, for these reasons, they can offer a limited temperature reduction, similar is the case of cooling via heat pipes. Active cooling systems [8,9], such as forced air circulation, 
hydraulic or thermoelectric cooling, have higher heat transfer rates compared to natural air circulation air and independence on wind direction and speed [10]. As disadvantages, they have high initial maintenance costs, an electricity consumption associated with an electricity consumption, and they are noisy systems.

Recently a new passive solution has been developed as a cooling system of modules, namely, through the exploitation of phase change materials (PCM) [11-13]. These materials are proving to be a good application [14]. PCMs use latent heat to absorb a large amount of energy and keep the panel cool. Dissimilar to sensitive heat, which is associated with an increase in temperature, the phase change occurs at a nearly constant temperature. PCMs absorb a large amount of heat during the solid-liquid phase change, and this allows to have smaller sizes with equal absorbed heat. In addition, reaching a lower temperature, self-discharge thermal losses are reduced, compared to fluids such as water, or air that can reach higher temperatures. In addition, maintenance is not usually required and there is no associated power consumption, as there are no fluids to be handled. The advantages of the application of the change phase materials in the back side of a photovoltaic module have already been studied.

Abdulmunem et al. [15] investigated the effects of the tilt angle of a PV panel from $0^{\circ}$ to $90^{\circ}$ obtaining a minor cell temperature in a range of $0.4 \%$ to $12 \%$. Huang [16] conducted an experimental investigation combining two different PCMs achieving the highest temperature reduction. Sharma et al. [17] experimentally obtained a reduction of 3.8 ${ }^{\circ} \mathrm{C}$ of the panel with an increase in the open-circuit voltage of $4.4 \%$, at an incident radiation of $1000 \mathrm{~W} / \mathrm{m}^{2}$. Hasan et al. [18] monitored over a one-year period the performance of a PV panel integrated with phase change materials. The annual electrical energy yield increased by $5.9 \%$ in hot climatic conditions.

The performance of PCMs coupled with PV panels has also been investigated numerically, to understand the working mechanism of the heat transfer and the parametric optimization [19]. These studies are divided into one-dimension (1D) [20], two-dimensions (2D) [21] and three-dimensions (3D) model analyses [22].

Phase change materials suffer frow a low thermal conductivity, and this represents an obstacle to the heat transfer rate. For instance, a paraffin wax has a thermal conductivity of around $0.2 \mathrm{~W} / \mathrm{m} \mathrm{K}$. Over the years, many strategies have been tested with the aim of increasing this parameter [23]. One of these consists of adding high thermal conductive nanoparticles in the PCM matrix, as they work as a "thermal bridge" for the heat flow. Studies focused on the quantification of the conductivity enhancement, on the thermal stability, on chemical compatibility and on the optimization of the arrangement of the particles in the PCM matrix. Sari et Karaipekli [24] proved that the thermal conductivity of a PCM increase with the percentage content of graphene. Wang et al. [25] introduced expanded graphite in a paraffin wax and obtained an improvement of the conductivity up to $12 \mathrm{~W} / \mathrm{m} \mathrm{K}$ with a mass percentage of graphite of $20 \% \mathrm{wt}$. For other percentages, $2 \% \mathrm{wt}$, $5 \% \mathrm{wt}, 10 \% \mathrm{wt}$ and $15 \% \mathrm{wt}$, the thermal conductivity resulted in 2.1, 4.0,13.6 and 20.4 times higher than pure paraffin. Other nanoparticles have been tested with the same aim. The most promising are $\mathrm{TiO}_{2}$ with a thermal conductivity increased by $47 \%$ with a mass ratio of $3 \%$ wt [26], $\mathrm{SiO}_{2}$ with time saved during the melting process of $25 \%$ obtained with a mass content of $1 \%$ wt [27], carbon nanotubes [28] and $\mathrm{Al}_{2} \mathrm{O}_{3}$ [29]. Ahmadi et al. [30] infiltrated the PCM to a PS-CNT (polystyrene-carbon nanotube) foam, finding a good increase in PCM conductivity. Alternatively, many studies have been conducted on the effect of metallic fins as a medium for heat transfer from the PV module to the PCM [31,32]. Fins allow to increase the contact surface between the panel and PCM and are usually metallic with high thermal conductivity. Abdulmunem et Jalil [33] obtained an improvement of $5 \%$ with the introduction of fins compared to traditional phase change materials.

This paper investigates the energy performance of a PV panel cooled by an innovative hybrid graphene/fins/phase change materials technology. The innovation consists of combining different strategies, aiming at optimizing the melting process. Aluminum fins work as a thermal bridge between the back of the FV panel and the PCM, while the presence 
of graphene nanoparticles increases the thermal conductivity of PCM. The procedure for preparing samples is widely presented in the paper. Initially, the proposed solution is tested under a solar simulator with controllable parameters (such as radiation and ambient temperature). The enhanced panel is compared to the reference case, namely, the pure panel, under the same conditions. The aim is to obtain a minor frontal temperature in the PV panel cooled by the hybrid system. This way the conversion yield increases, and the panel produces a greater amount of energy with an equal incident radiation. Later, the two configurations are tested simultaneously outdoors, to investigate the performances under natural atmospheric conditions. The system is analyzed continuously for three days, both during the day and night, to study the performances (melting and solidification cycles of PCM) under external conditions. The paper is organized as follows: in Section 2, a detailed description is provided as regards to the materials utilized and the design phase, results are discussed in Section 3 and, in Section 4, the conclusions are listed.

\section{Materials and Methods}

A common monocrystalline PV panel was experimentally compared to an enhanced panel, integrated in the rear part with graphene/fins/phase change material. A monocrystalline panel $(650 \times 505 \mathrm{~mm})$ was chosen. The rated power was $40 \mathrm{~W}$, with $17.8 \mathrm{~V}$ module voltage and 2.3 A nominal current, while the open-circuit voltage and the short-circuit current were $21.3 \mathrm{~V}$ and $2.7 \mathrm{~A}$, respectively.

Paraffin wax was chosen as phase change material (PCM), the RT35 HC, produced by the Rubitherm company (Germany). The most important properties are reported in Table 1.

Table 1. Characteristics of PCMs used.

\begin{tabular}{ll}
\hline Characteristics & RT 35 HC \\
\hline Melting area $\left({ }^{\circ} \mathrm{C}\right)$ & $34-36$ peak 35 \\
Congealing area $\left({ }^{\circ} \mathrm{C}\right)$ & $36-34$ peak 35 \\
Volume expansion $(\%)$ & 12 \\
Latent heat $(\mathrm{kJ} / \mathrm{kg})$ & 240 \\
Heat conductivity $\left(\mathrm{W} / \mathrm{m}^{2} \mathrm{~K}\right)$ & 0.2 \\
Specific heat capacity $(\mathrm{kJ} / \mathrm{kg} \mathrm{K})$ & 2 \\
Liquid density $(\mathrm{kg} / \mathrm{l})$ & 0.77 \\
Solid density $(\mathrm{kg} / \mathrm{l})$ & 0.88 \\
\hline
\end{tabular}

The first enhancement proposed to increase the low thermal conductivity of PCM was the addition of graphene powder, in a percentage of $2 \mathrm{wt} \%$. It consisted of nanoparticles (average diameter $50 \mu \mathrm{m}$ and thickness $3 \mathrm{~nm}$ ), in appearance such as a powder, with high thermal conductivity (between 3000 and $5000 \mathrm{~W} / \mathrm{m}^{\circ} \mathrm{C}$ ). Graphene was characterized by low density and chemical activity, large specific surface area $\left(300-500 \mathrm{~m}^{2} / \mathrm{g}\right)$ and high infrared emissivity (0.95). The purpose was to distribute graphene powder evenly in the PCM matrix and increase its thermal conductivity. The preparation of the PCM/graphene sample consisted of different steps (Figure 1). First, the PCM was completely melted and then the graphene powder was added. The mixture is mechanically stirred for $3 \mathrm{~h}$ at a temperature of around $70^{\circ} \mathrm{C}$. This ensured uniformity of the composite. Afterwards, the mixture underwent a further treatment by an ultrasonic processor for $30 \mathrm{~min}$ at $40{ }^{\circ} \mathrm{C}$ for appropriate dispersion of molecules. 

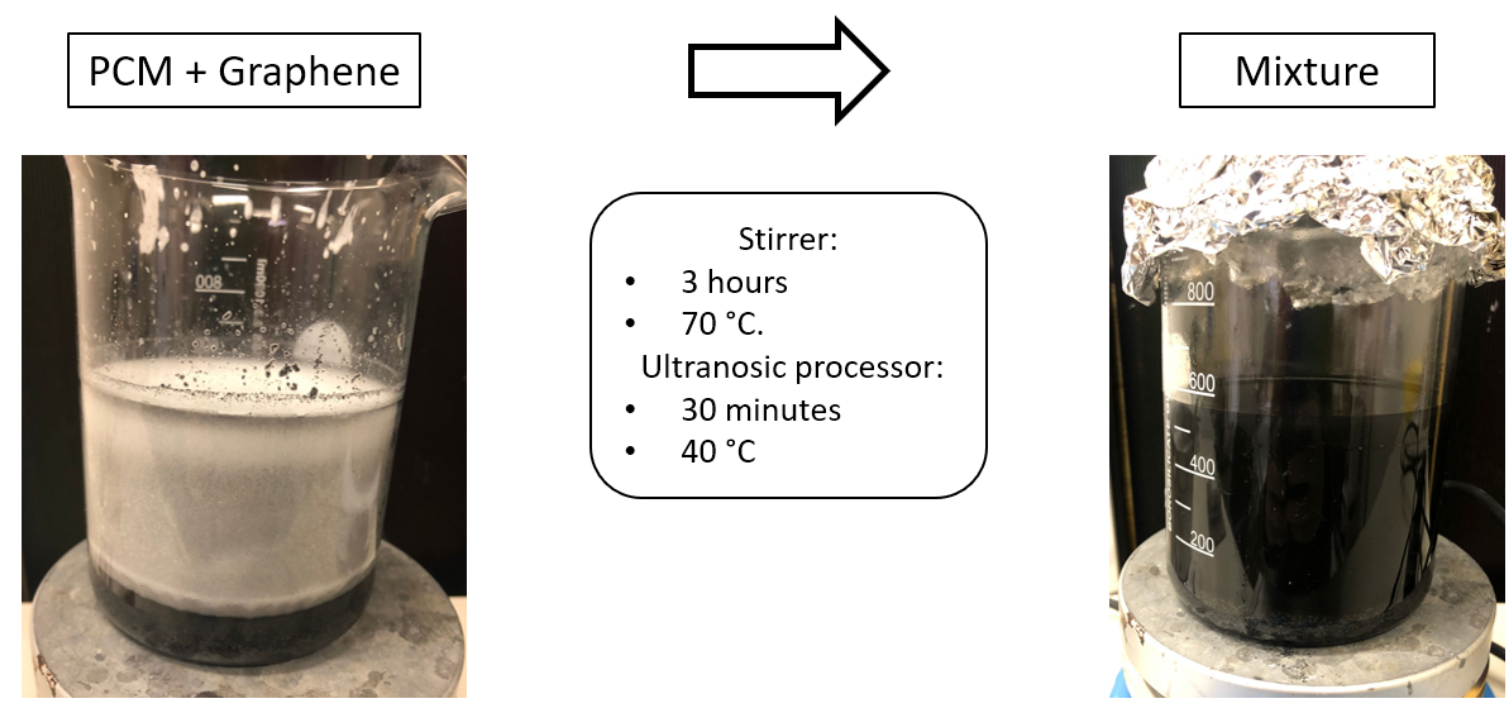

Figure 1. Preparation of the PCM/graphene mixture.

The second enhancement concerned the implementation of aluminum fins. This way, the contact area between the PCM and the PV panel was greatly increased, and they worked as "thermal bridges" between the PV module and the PCM-graphene mixture. Fins were obtained from cutting and bending of strips from a thin aluminum sheet glued to the back surface of the panel.

The containment box was composed of plexiglass to ensure transparency and to visualize the melting process. The external dimensions of the box were $65 \times 50 \times 2.5 \mathrm{~cm}$, while the internal ones were $64 \times 49 \times 2.0 \mathrm{~cm}$. Once the $\mathrm{PCM} /$ graphene preparation was completed, the liquid mixture was poured in the plexiglass box and then it was closed with the panel where the fins were glued.

The proposed system appeared as in Figure 2. A set of thermocouples (red bullets in figure) were mounted throughout the system to monitor the temperatures. One was mounted frontally on the PV panel and another on the back, glued on the aluminum sheet. Two thermocouples were placed in the PCM, at $7 \mathrm{~mm}$ from each other, to monitor the heat flow and phase change process of the PCM; the last one, on the rear surface of the plexiglass. Thermocouples were T type (copper-constantan) with a sensitivity of $48.2 \mu \mathrm{V} /{ }^{\circ} \mathrm{C}$ and a measurement range from $-200{ }^{\circ} \mathrm{C}$ to $400{ }^{\circ} \mathrm{C}$. The global solar radiation was monitored by a pyranometer, model DPA/ESR 154, with a range of measure from 0 to $2000 \mathrm{~W} / \mathrm{m}^{2}$, a sensitivity of $10.88 \mu \mathrm{V} / \mathrm{Wm}^{-2}$ and a linearity of $0.75 \%$.

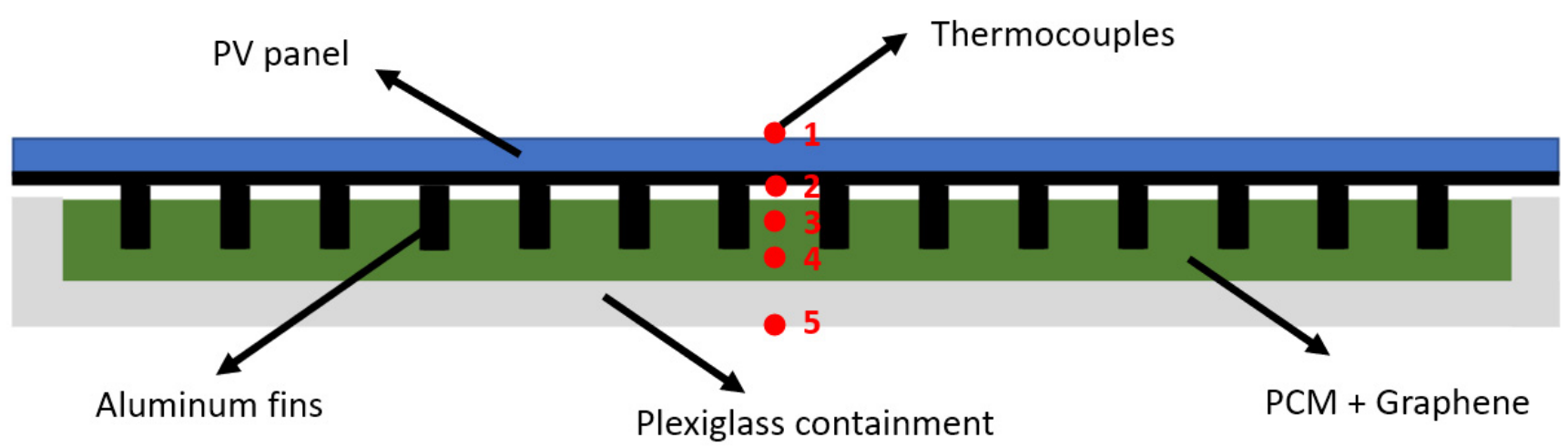

Figure 2. A schematic section of the proposed PV-PCM panel.

Two sets of measures were organized. The first one was performed indoors under a solar simulator [34], useful to allow repeatable tests under the same conditions (such as the incident radiation and the ambient temperature). The solar simulator consisted of 
20 metal halide lamps that could irradiate uniformly a horizontal area of around $2 \times 1 \mathrm{~m}$. The spectral content of the artificial source, as indicated in data sheet depicted in Figure 3 , was close to that of the natural sunshine.

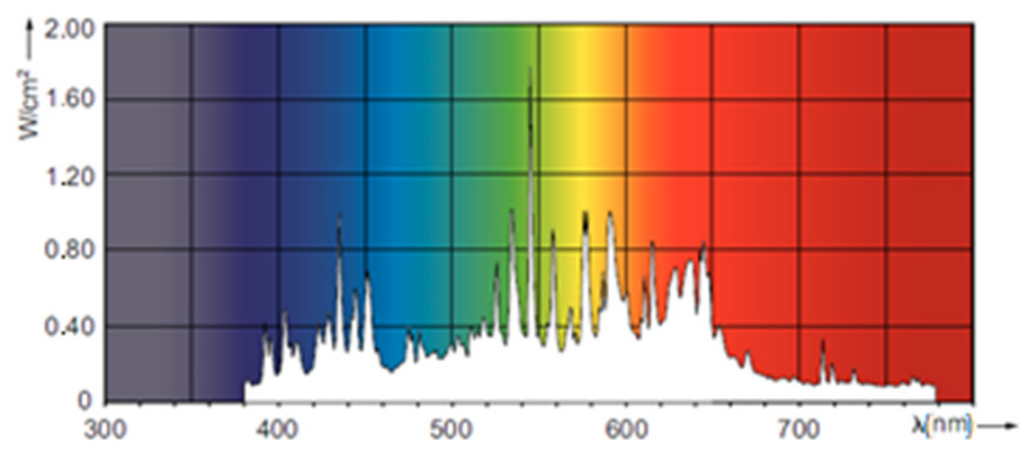

Figure 3. Spectral content of the lamps.

The intensity and the angle of incidence of the simulated radiation on the target area were adjustable. The test aimed to prove the advantages of the proposed system (enhanced PV panel) compared to the reference case. The comparison was based on the front temperature of the panel, which influenced the electric conversion yield. A minor temperature corresponded to a major yield. In addition, the presence of PCM also allowed a thermal energy recovery, that was completely lost in the reference case. The second set of measurements was performed outdoors to verify the data and the performance obtained indoors under real conditions. Outdoor tests also allowed to investigate the behavior during the day and night. In this case, the simple panel and the enhanced one were tested simultaneously under the same conditions, aiming to obtain a comparison.

\section{Results and Discussions}

\subsection{Indoor Characterization}

Indoor analysis lasted $2 \mathrm{~h}$, a time sufficient to reach a steady-state temperature regime. In Figure 4, the experimental setup is shown.

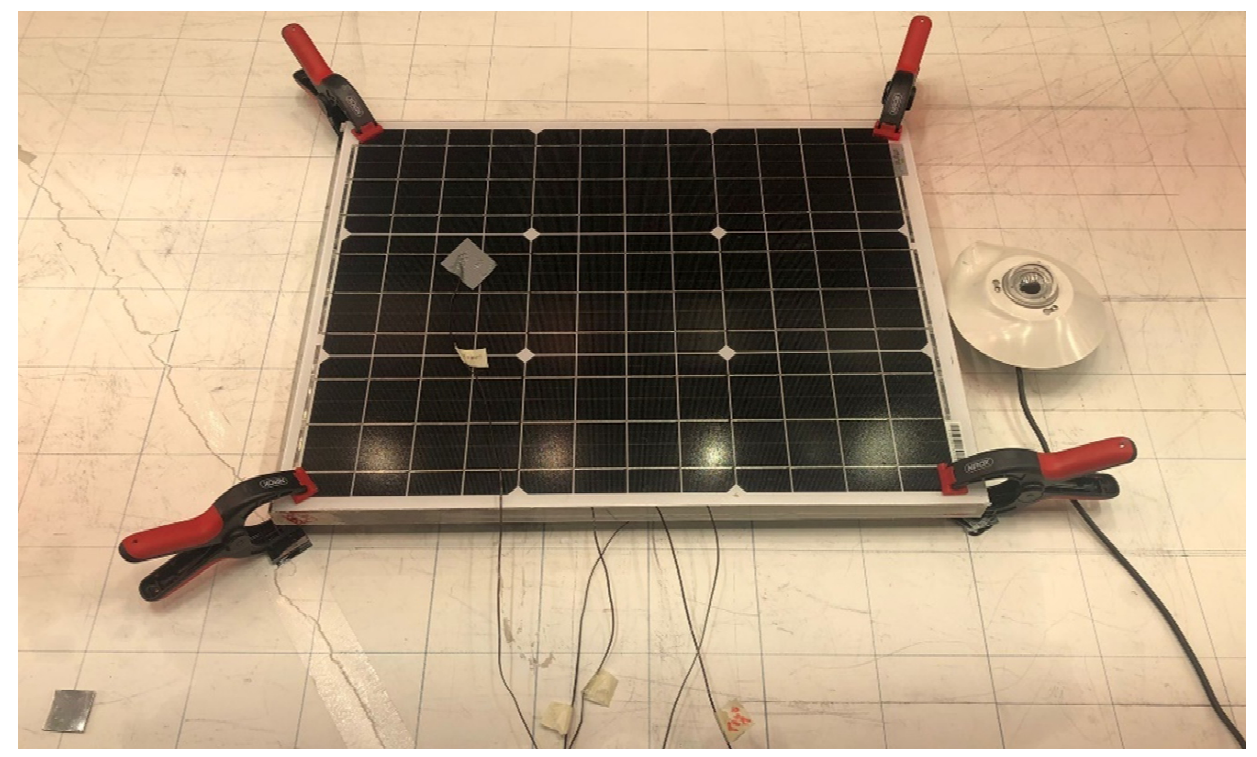

Figure 4. Experimental indoor setup.

Both tests were performed at a simulated solar radiation of $1000 \mathrm{~W} / \mathrm{m}^{2}$. Both trends are depicted in Figure 5, where the blue line indicates the references case test and the red 
one the enhanced panel. After a ramping of about $3 \mathrm{~min}$, necessary to the lamps to reach the nominal power, the simulated radiation was around $1000 \mathrm{~W} / \mathrm{m}^{2}$.

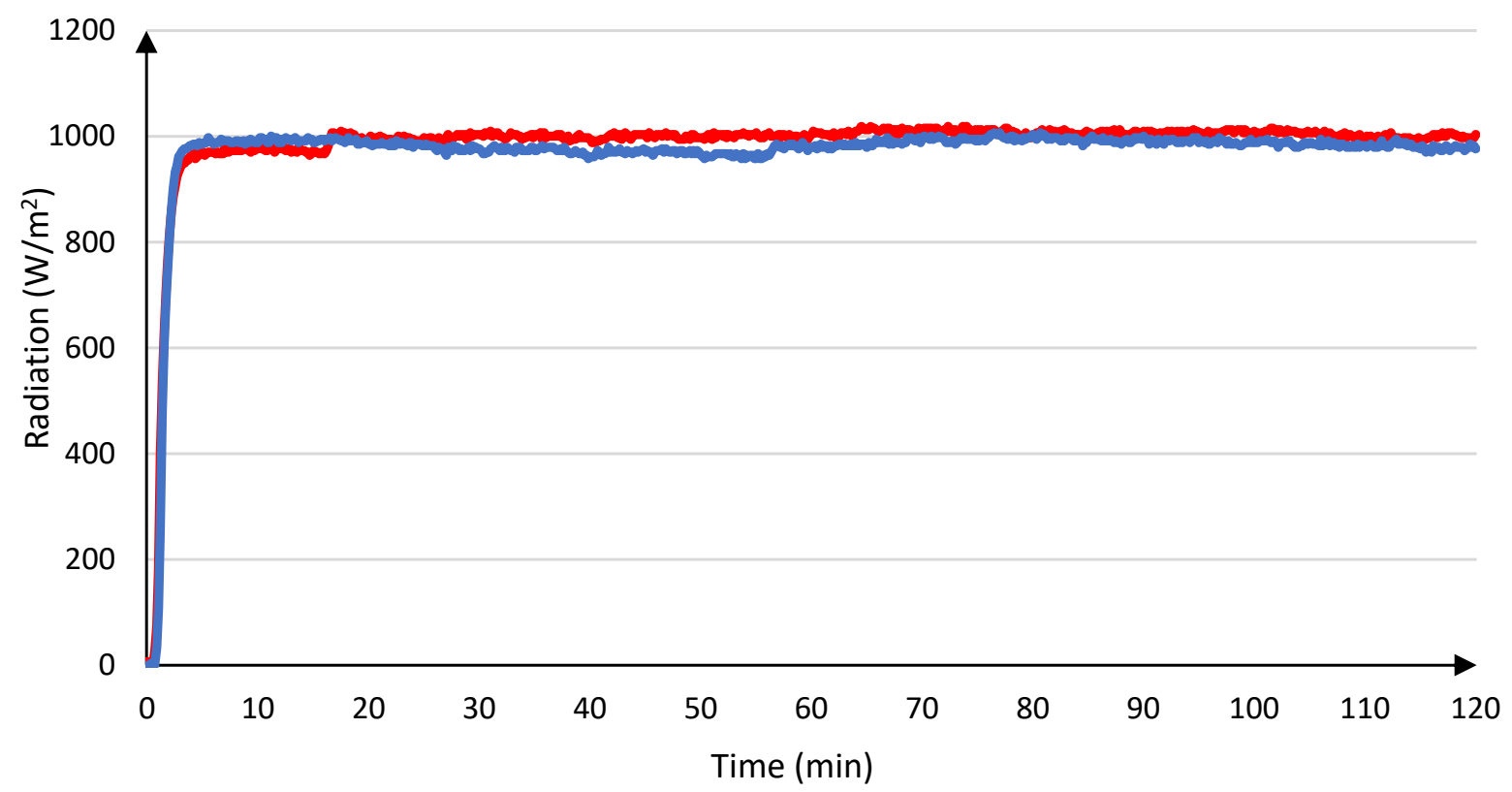

Figure 5. Trend of the simulated radiation for the reference case (blue line) and the enhanced panel (red line).

The comparison of the temperatures between the reference case and the enhanced PV panel is shown in Figure 6. The front temperature of the pure panel is depicted with the red line, while the blue line indicates the front temperature of the graphene/fins/PCM PV system.

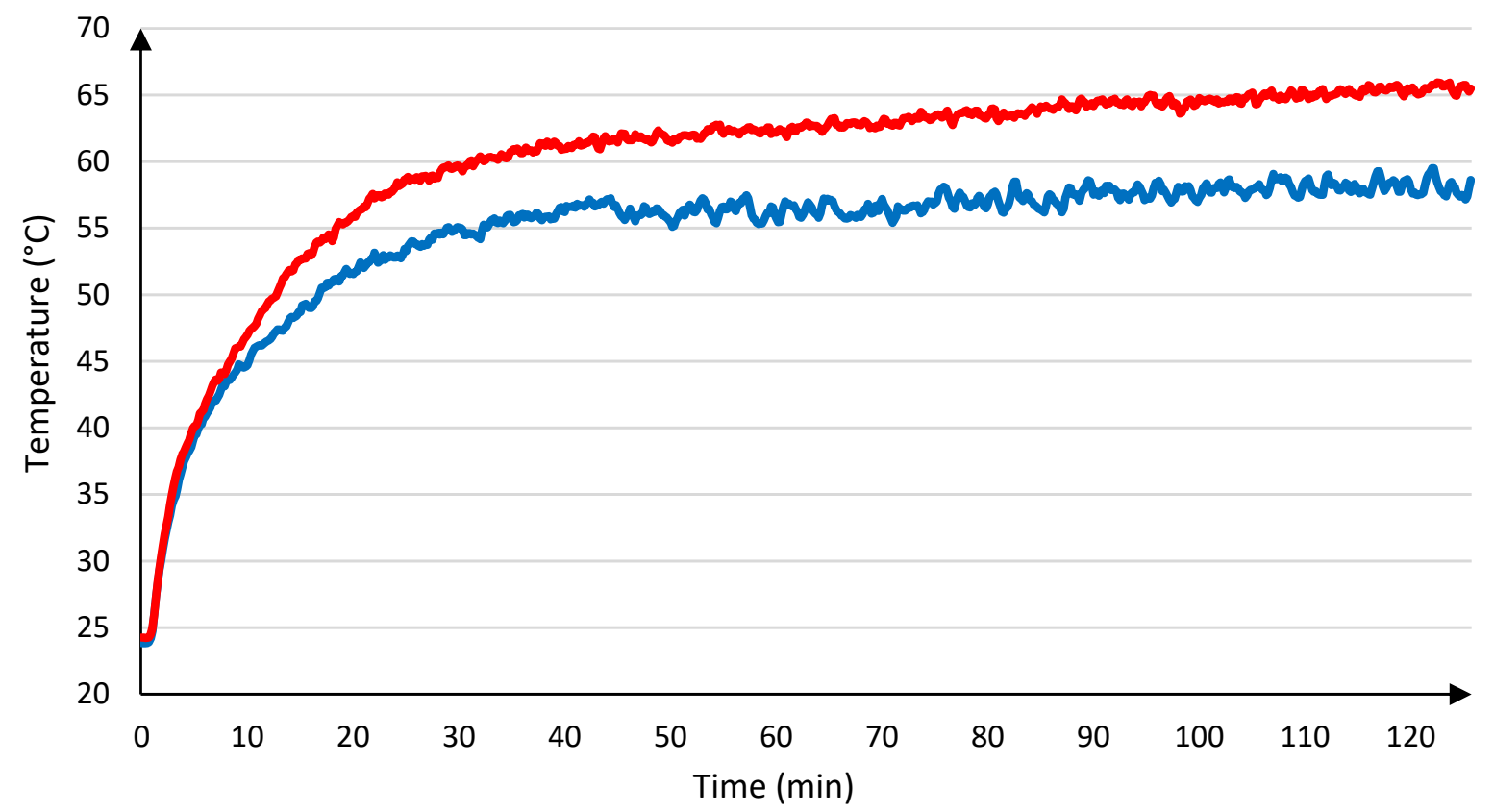

Figure 6. Comparison between the front temperature of the reference case (red line) and the enhanced panel (blue line) over the two-hours test.

After around ten minutes, where the temperatures followed the same trend, at around $45^{\circ} \mathrm{C}$, the reference panel became warmer. At the end of the two hours, the front thermocouple mounted on the reference panel measured a temperature of $65.4^{\circ} \mathrm{C}$, while on 
the enhanced panel $58.6^{\circ} \mathrm{C}$. The time taken to reach a steady-state temperature condition was investigated to estimate the major conductivity obtained by adding the graphene and the aluminum fins into the PCM. The slope of the trend was calculated by the following Equation (1):

$$
\Delta(i)=\frac{\operatorname{Tm}(i)-\operatorname{Tm}(i-1)}{\operatorname{Tm}(i)} \times 100
$$

where $i$ is the time step, set in a minute, and $\operatorname{Tm}(i)$ and $\operatorname{Tm}(i-1)$ are the average temperatures over a minute in the current time step and in the previous one, respectively. $\Delta$ is the slope of the temperature trend. The trend is considered in a steady-state regime when the slope $(\Delta)$ was in a range of convergence of $\pm 1 \%$. Results were post-processed through the function "polyval" and "polyfit" on the software MATLAB to eliminate the signal noise. The results are shown in Figure 7. The increased conductivity was proved, as the reference case reached the steady-state condition after 20 min while the enhanced panel after only $14 \mathrm{~min}$. This allowed the panel to be colder and, accordingly, the electric yield increased.

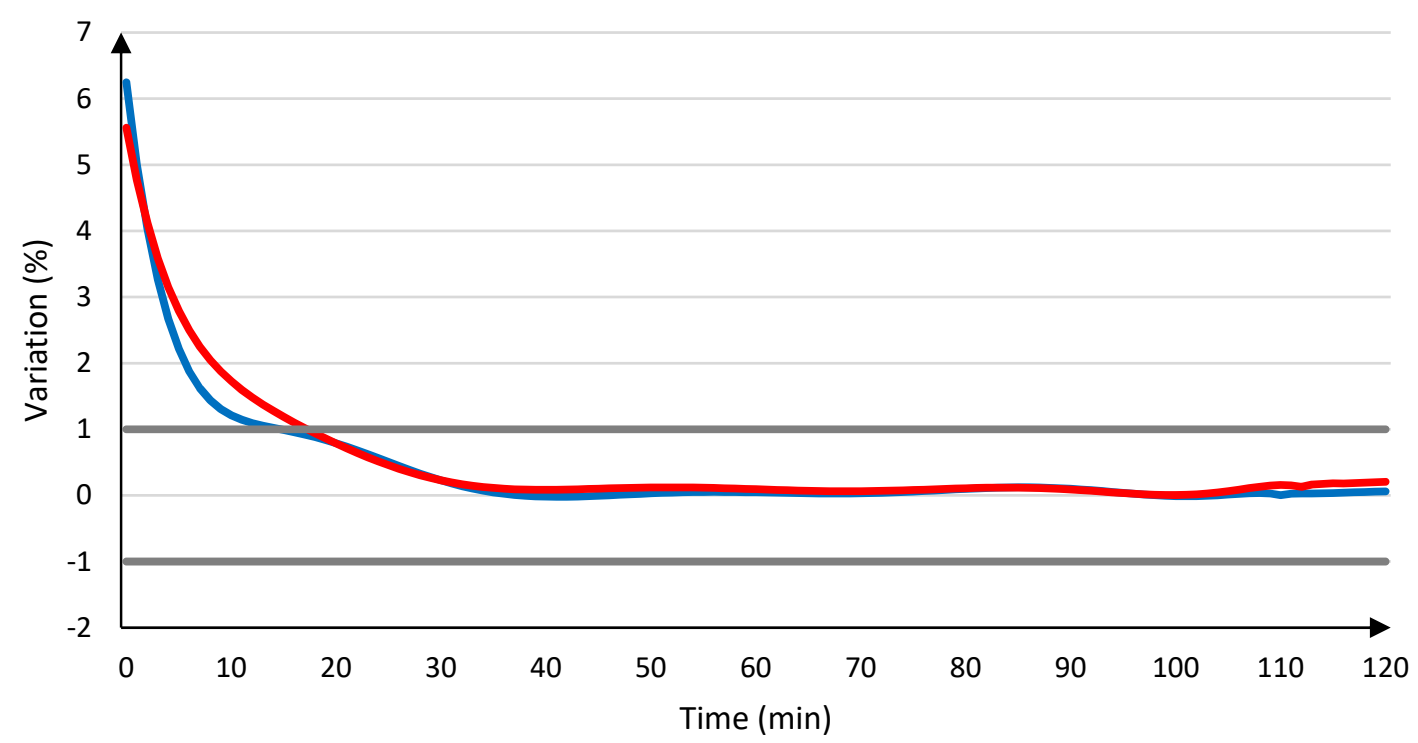

Figure 7. Convergence to the steady state regime (the blue line indicates the enhanced panel and the red one the reference case).

Globally, over the two hours test, the temperature of the enhanced panel was $6{ }^{\circ} \mathrm{C}$ colder than the reference case one. Hypothesizing a temperature coefficient of $0.5 \% /{ }^{\circ} \mathrm{C}$ for the monocrystalline PV panel, an increase of $3 \%$ in the electric yield was obtained. In Table 2, all the results are summarized.

Table 2. Indoor test results.

\begin{tabular}{ccccc}
\hline & $\begin{array}{c}\text { T Average } \\
\left({ }^{\circ} \mathbf{C}\right)\end{array}$ & T Peak $\left({ }^{\circ} \mathbf{C}\right)$ & $\begin{array}{c}\text { Ramping Time } \\
\text { (Minutes) }\end{array}$ & $\begin{array}{c}\text { Average Solar } \\
\text { Radiation }\left(\mathbf{W} / \mathbf{m}^{2}\right)\end{array}$ \\
\hline $\begin{array}{c}\text { Ref case } \\
\text { Enhanced panel }\end{array}$ & 60.01 & 65.4 & 20 & 977 \\
\hline
\end{tabular}

The enhanced panel was monitored for more than three hours, to allow the melting process to be completed. In Figure 8, the end of the process was visible in a change of slope. This occurred around $35^{\circ} \mathrm{C}$, for the first thermocouple (orange line), then dipped into the PCM after 1:20 $\mathrm{h}$ from the beginning of the test. For the second one, this happened after 2:30 $\mathrm{h}$ (blue line). When the change of slope occurred for the light blue line $(2: 45 \mathrm{~h})$, representing the thermocouple mounted on the plexiglass box, the melting process was completed. In Figure 8, the trend of all temperatures is shown. 


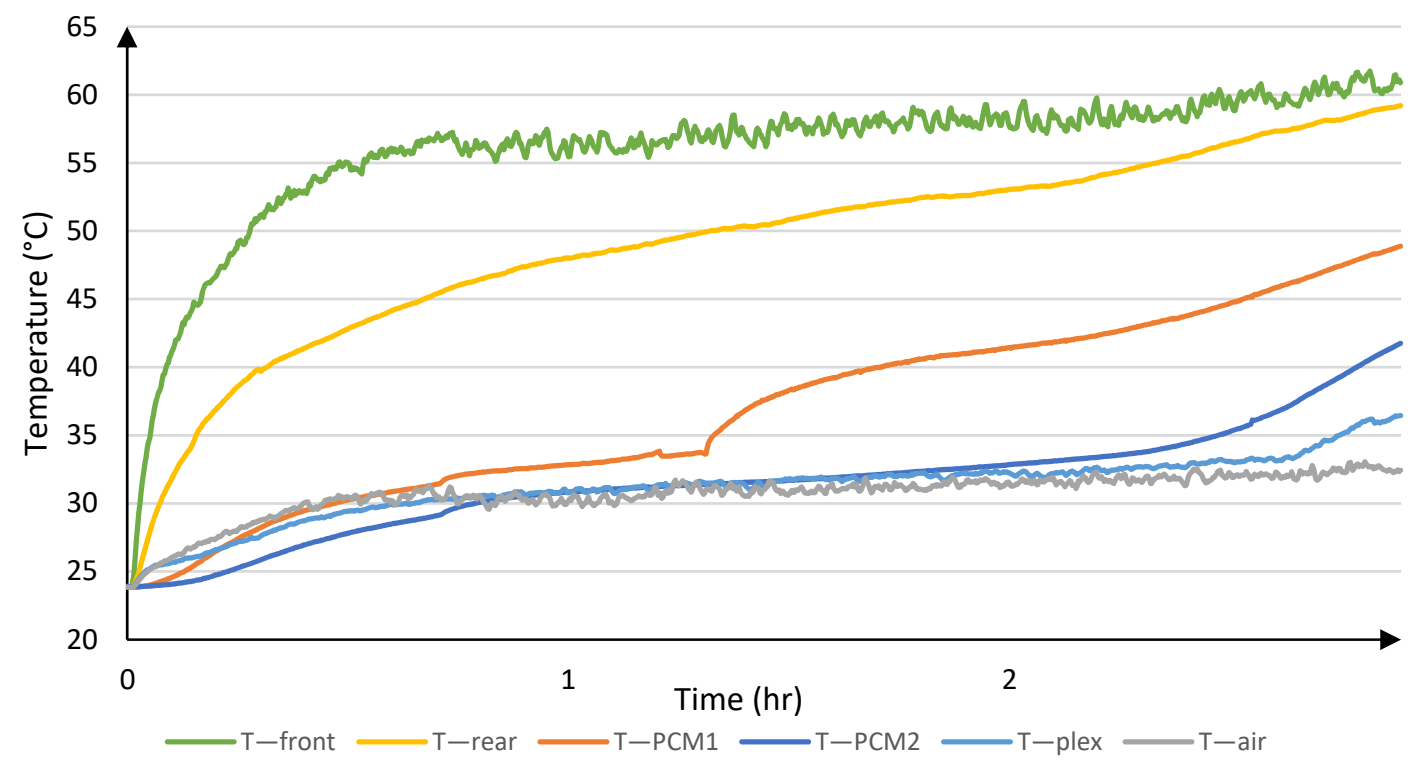

Figure 8. Monitoring of temperatures of the enhanced panel during the indoor test.

Figure 9 visually shows the sequence of the same melting process.
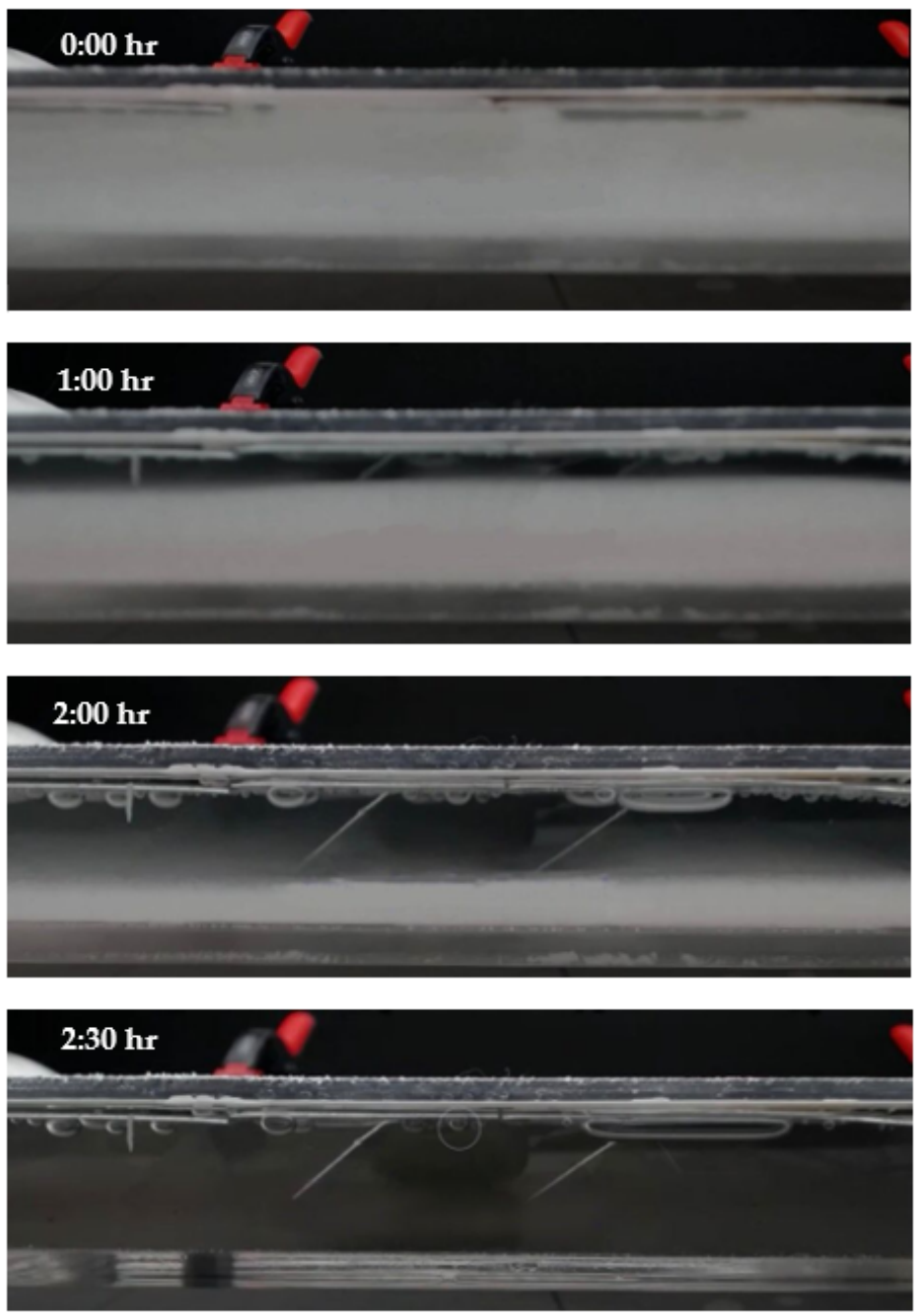

Figure 9. Photo sequence of the melting process. 


\subsection{Outdoor Performance}

The outdoor analysis lasted over 3 days, to monitor the performance of the proposed system during the day-night cycle. The setup is shown in Figure 10.

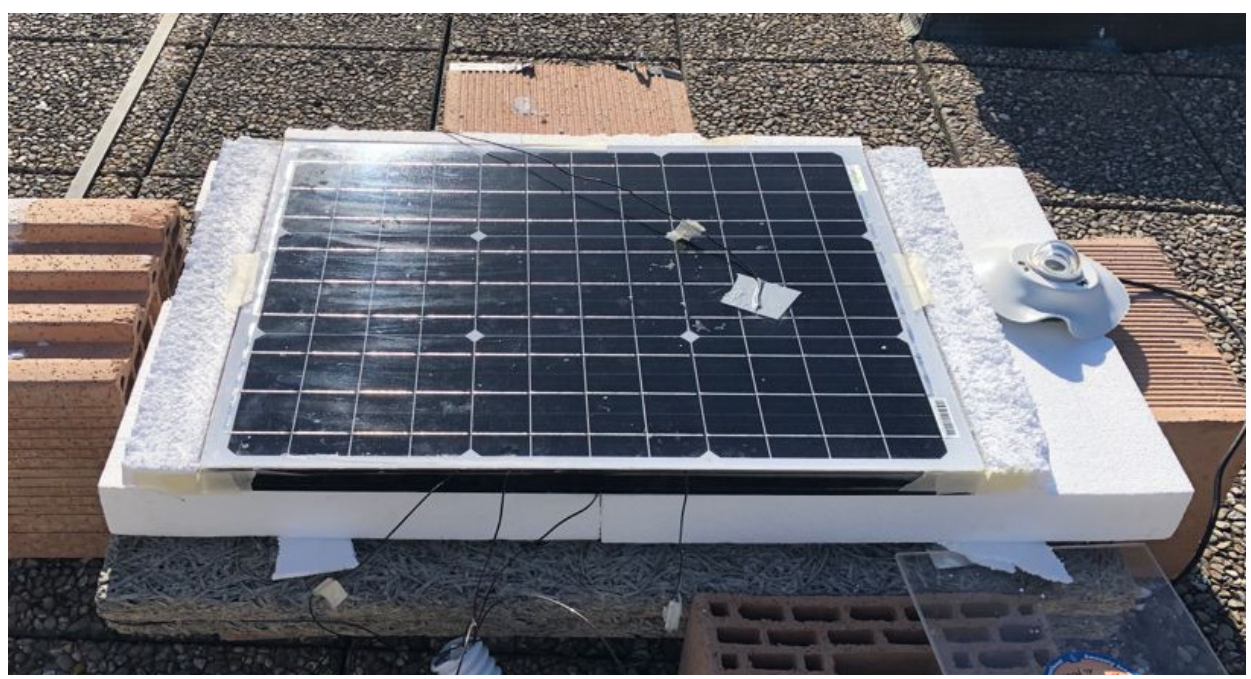

Figure 10. Experimental outdoor setup.

The reference case and the enhanced panel were investigated in parallel under the same atmospheric conditions. In Figure 11, the front temperature of the simple PV panel (red line) and the enhanced panel (blue line) are depicted. Results showed that the enhanced panel had a minor temperature in the morning, while during the remaining hours it was warmer than the simple panel. Numerically, the deviation of the two temperatures is represented in Figure 12. Positive numbers indicate that the enhanced panel was colder, vice versa for the negative ones. The maximum difference measured was almost $6{ }^{\circ} \mathrm{C}$. Considering a temperature coefficient of $0.5 \% /{ }^{\circ} \mathrm{C}$ for a monocrystalline panel, this means an increase in the electric conversion of 3\%. During the evening and at night, the PCM maintained the panel warmer, but without affecting the electric yield as there was no solar radiation.

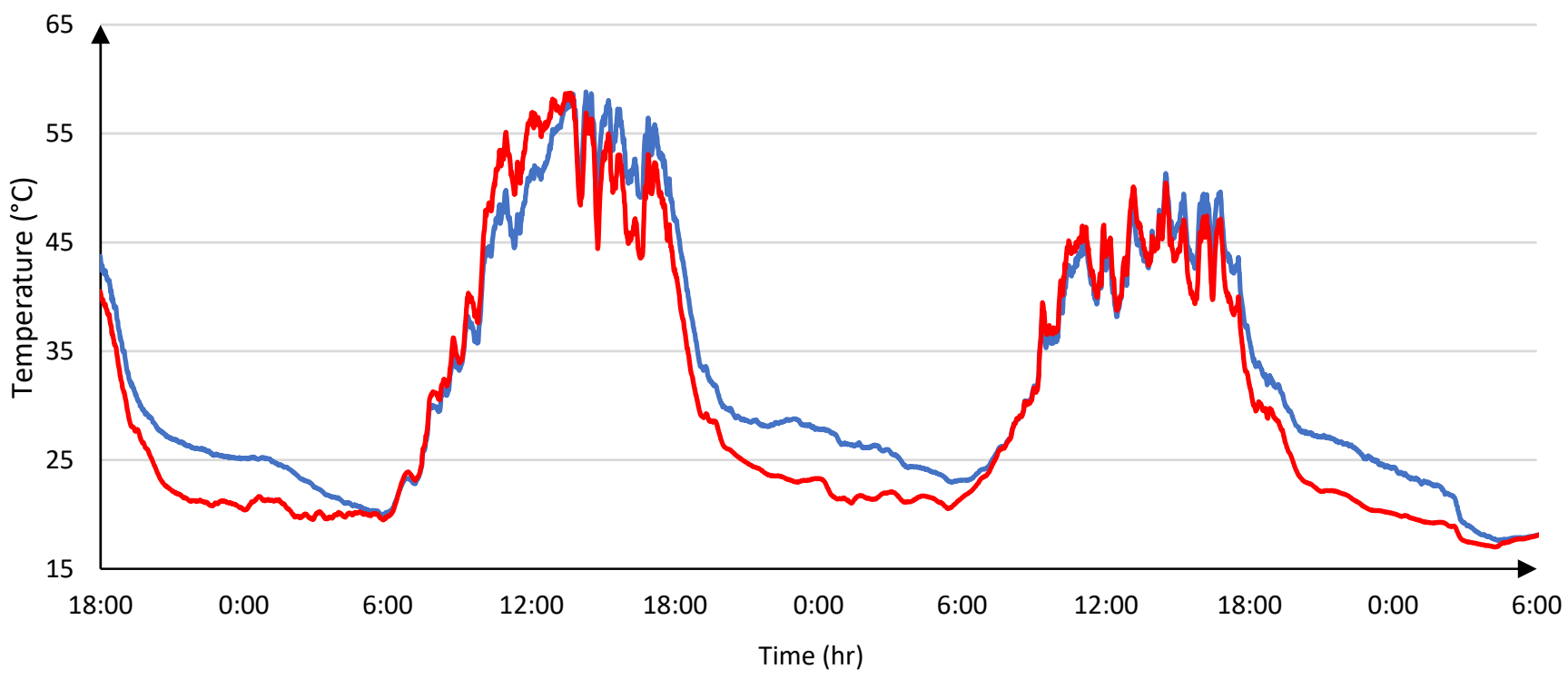

Figure 11. Front temperature of the simple PV panel (red line) and the enhanced panel (blue line). 


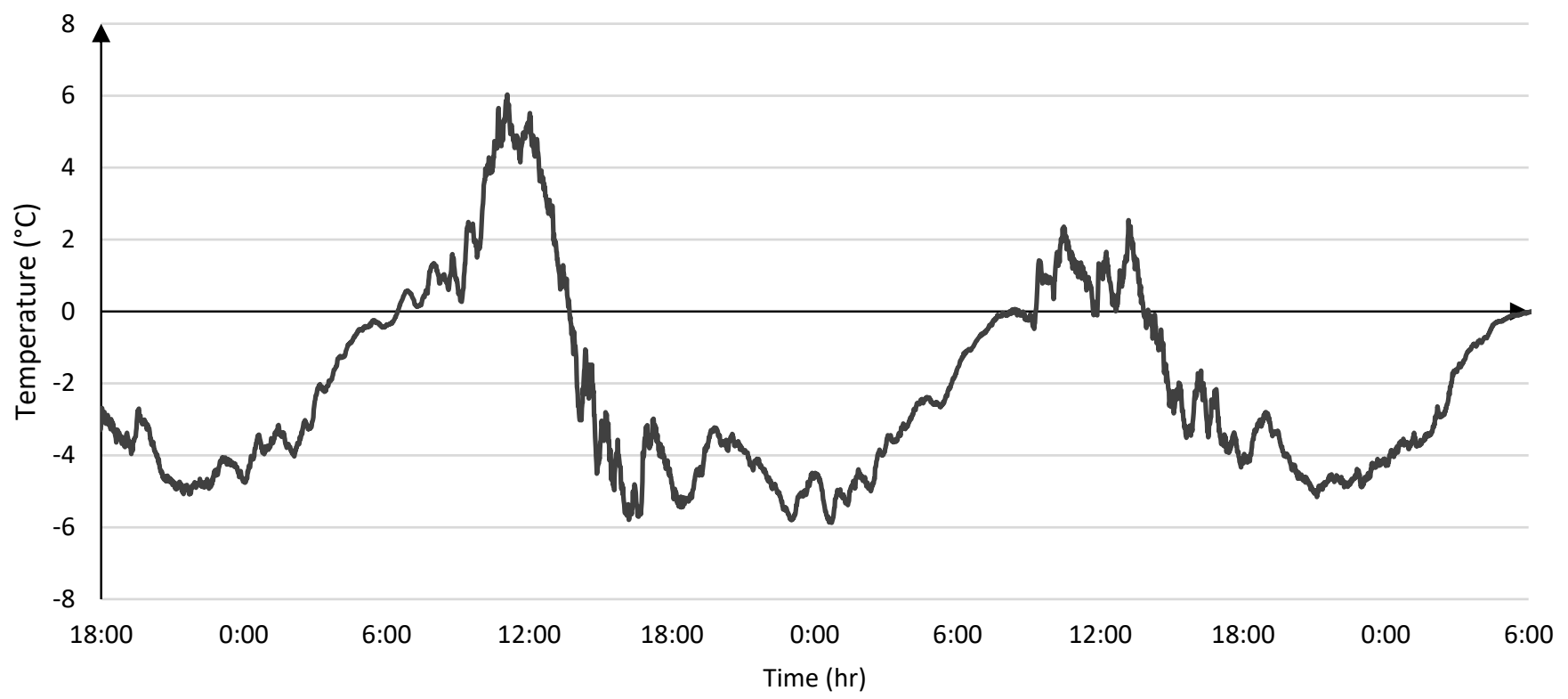

Figure 12. Deviation between the reference case and the enhanced panel.

The different performances resulting during the daytime hours, made a greater deepening necessary. An analysis was differentiated in the function of the state of the PCM, to find a correlation. Figures 13-15 show the temperature difference in the two systems with solid state PCM, during phase change and liquid phase, respectively. The red line indicates the front temperature of the simple panel, while the blue one the enhanced panel. The black line is the average of the two thermocouples dipped into the PCM, to measure the thermal level of the PCM.

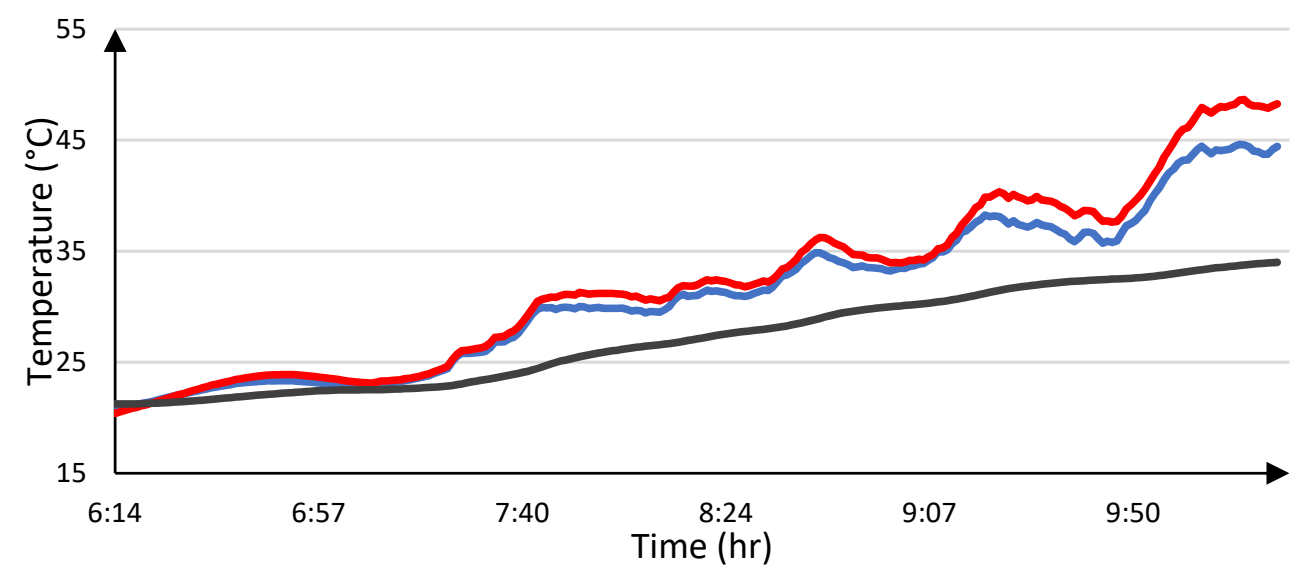

Figure 13. Temperatures during solid state PCM. The red line indicates the front temperature of the simple panel, the blue one the enhanced panel. The black line is the average of the two thermocouples dipped into the PCM. 


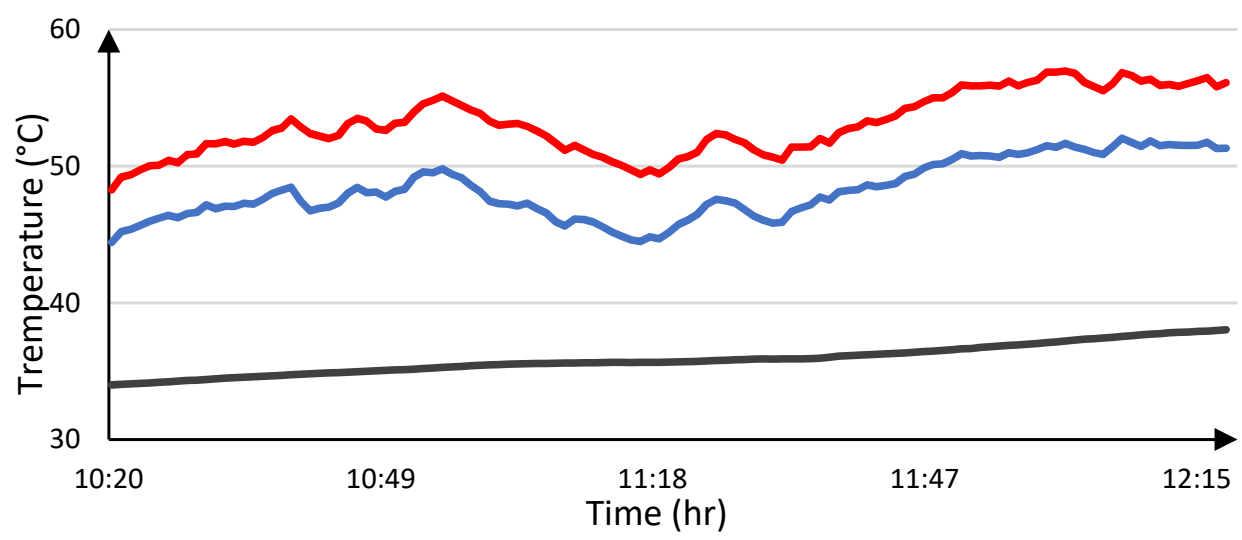

Figure 14. Temperatures during the melting process. The red line indicates the front temperature of the simple panel, the blue one the enhanced panel. The black line is the average of the two thermocouples dipped into the PCM.

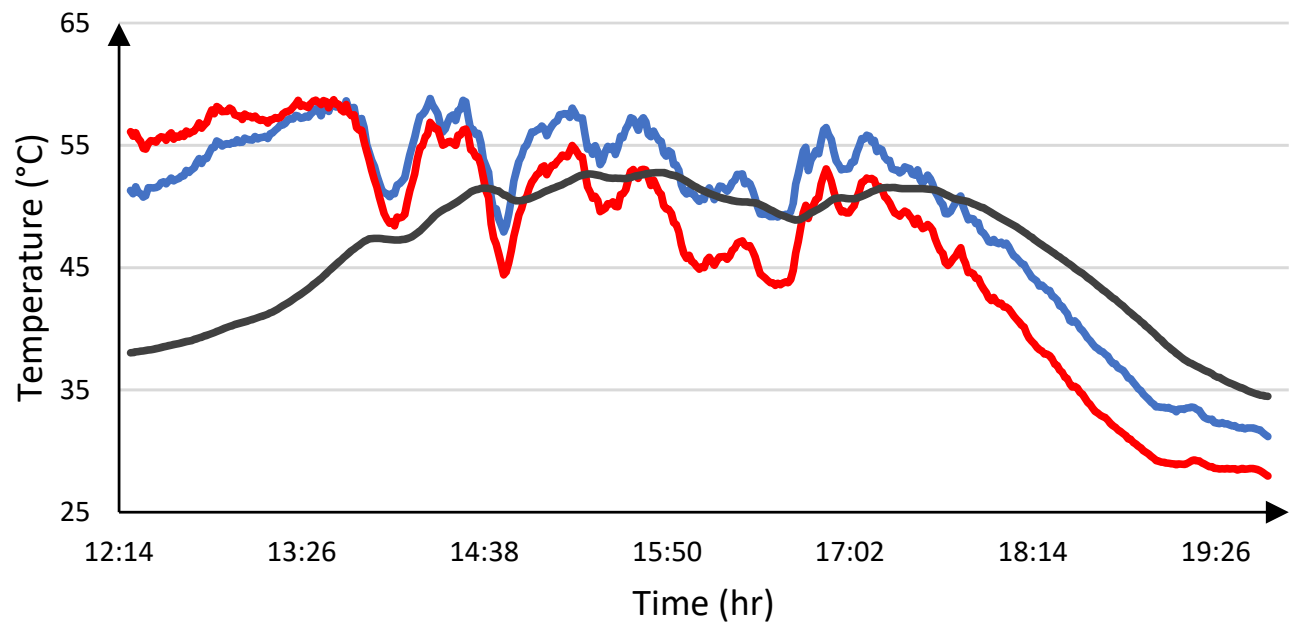

Figure 15. Temperatures during liquid state PCM. The red line indicates the front temperature of the simple panel, the blue one the enhanced panel. The black line is the average of the two thermocouples dipped into the PCM.

Figure 13 shows the difference of temperature between the two system while the PCM was still solid. As the PCM temperature increased, the two front temperatures started to differ slightly. In this period, the average temperature of the panel was $32.1^{\circ} \mathrm{C}$, while in the case of the enhanced one, it was $30.9^{\circ} \mathrm{C}$. This meant that in the solid state, an increase in the electric yield of around $0.5 \%$ was obtained. In Figure 14, the same trends are depicted during the solid-liquid phase change. The temperature of the PCM was nearly constant, and the different between the two panels was more pronounced. The melting process lasted about $2 \mathrm{~h}$, and the enhanced panel was about $5^{\circ} \mathrm{C}$ colder $\left(53{ }^{\circ} \mathrm{C}\right.$ against $48.2{ }^{\circ} \mathrm{C}$ of the simple panel) with an increase in the yield of $2.5 \%$. Once the PCM was completely melted, the trend was reversed and the panel became increasingly warm, surpassing the reference one (Figure 15). In this phase, the enhanced panel turned out to be $2.8^{\circ} \mathrm{C}$ warmer with a decrease in the yield of $1.4 \%$. Globally, throughout the day, the enhanced panel was $0.5{ }^{\circ} \mathrm{C}$ warmer than the reference case. This was due to the negative contribution of the liquid phase, the only one with a negative deviation. The melting process, on the contrary, showed the best results. This meant that, once the melting process was completed, an extraction system shall be activated to return the PCM to the beginning of the melting zone and re-exploit the phase change. Accordingly, the difference in temperature between the two system was maximized. Results are reported in Table 3. 
Table 3. Results of the electric yield in the different states.

\begin{tabular}{ccccc}
\hline & $\mathbf{T}_{\text {avg }} \mathbf{P V}$ & $\mathbf{T}_{\text {avg }}$ PV-PCM & $\boldsymbol{\Delta} \mathbf{T}$ & $\boldsymbol{\Delta}$ yield (\%) \\
\hline Solid state & 32.1 & 30.9 & 1.12 & 0.56 \\
Phase change & 53.09 & 48.2 & 4.87 & 2.44 \\
Solid state & 47.09 & 49.8 & -2.79 & -1.40 \\
Global & 43.3 & 43.8 & -0.49 & -0.25 \\
\hline
\end{tabular}

The same analysis was conducted in regards to the thermal aspect. Table 4 summarized the results. The incident radiation was determined starting from data collected by the pyranometer. The heat absorbed $(Q)$ was calculated with the following equations:

$$
Q(i)=m \times c_{p} \times \Delta T(i),
$$

where $m$ is the mass and $c_{p}$ is the specific heat of the PCM. $\Delta T(i)$ is the difference of temperature at the time $i$ measured by the thermocouples. The thermal yield was defined as:

$$
\text { Yield }=\frac{\sum_{i} \text { radiation }(i)}{\sum_{i} Q(i)}
$$

where the two summations were calculated over the reference period (solid state, phase change and liquid state).

Table 4. Results of the thermal recovery in the different states.

\begin{tabular}{lrrr}
\hline & Radiation (MJ) & Heat Absorbed (MJ) & Yield (\%) \\
\hline Solid state & 0.376 & 0.117 & $31.1 \%$ \\
Phase change & 1.062 & 0.906 & $65.6 \%$ \\
Liquid state & 2.609 & 0.176 & $6.6 \%$ \\
Global & 4.028 & 1.199 & $29.7 \%$ \\
\hline
\end{tabular}

Results, as reported in Table 4, showed that the higher yield was obtained during the solid-liquid phase change (65\%). The solid state presented a $30 \%$ yield and the worst case was the liquid phase with only $6 \%$. Globally, the thermal yield of the proposed system was $30 \%$. Worth noting is the correlation between the thermal and electrical efficiency. During the phase change, the enhanced panel could absorb a relevant amount of the incident radiation $(65 \%)$. This allowed the panel to remain colder; in fact, during the same period, the largest increase in electrical efficiency was obtained (almost 2.5\%, as reported in Table 3). The same way, once the melting process was completed, the thermal and electric yield reached the minimum level. The liquid PCM could no longer absorb as much heat as previously to keep the panel cool. As a result, the performance precipitated. The thermal aspect confirmed that, at the end of the phase change, an extraction system would allow the maximization of both the thermal and electric yield.

Figure 16 shows the trend of temperature for all the thermocouples mounted on the proposed graphene/fins/phase change materials PV panel. The melting process during the morning hours and solidification process at night were clearly visible, highlighted in the figure. Both occurred at a nearly constant temperature, around $35^{\circ} \mathrm{C}$. This meant that, the day after, the PCM could start a new melting cycle, as it was completely solid. 


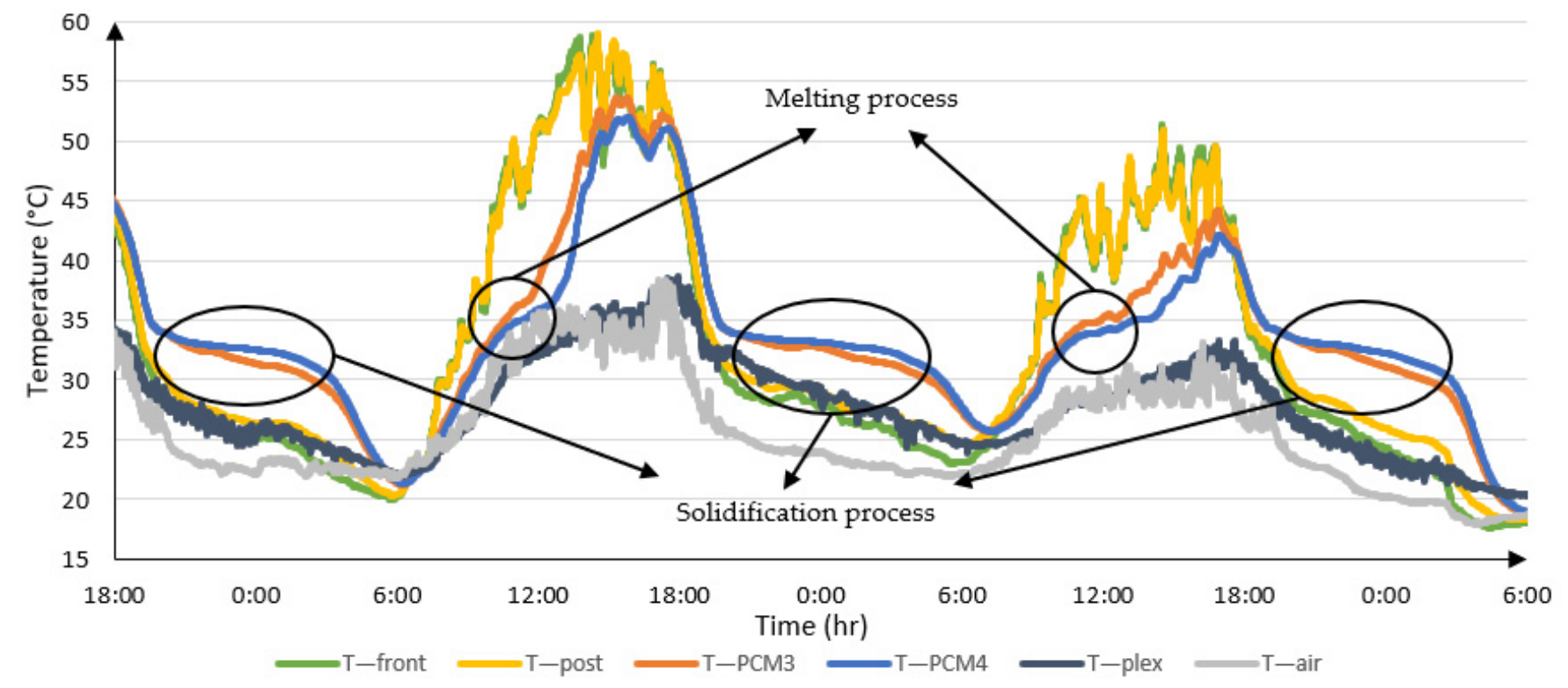

Figure 16. Monitoring of temperatures of the enhanced panel during the outdoor test.

\section{Conclusions}

This paper presented a hybrid cooling system for the thermal regulation of photovoltaic panels (PV). The innovative solution consisted of the design and construction of a box, applied on the back of the panel, containing a combination of fins/graphene/PCM. Aluminum fins were mounted on the rear surface of the panel and immersed in the PCM (RT 35 HC), working as a "thermal bridge". The graphene nanoparticles, equally distributed in the PCM, increased the thermal conductivity of the PCM. The procedure for preparing samples was presented in the paper. The proposed system was compared to a reference simple panel to investigate the performance improvements.

Indoor tests, under a solar simulator, aimed at comparing the front temperature of the two panels. Results showed that the enhanced panel was averagely $6{ }^{\circ} \mathrm{C}$ colder than the reference case, resulting in an increase in the electric yield of about $3 \%$.

Outdoors, the proposed solution and the simple panel were monitored simultaneously for two days. A detailed analysis in the function of the PCM state was performed. Results showed:

- During the solid phase, the two systems showed a similar temperature, the efficiency was slightly higher in the case of the hybrid panel $(0.5 \%)$.

- The solid-liquid phase change provided the best results. The hybrid panel was about $5{ }^{\circ} \mathrm{C}$ colder, with an efficiency increase of about $2.5 \%$.

- The liquid PCM did not absorb large amounts of heat, and the panel overheated. The hybrid panel showed higher temperatures, and the efficiency was reduced.

In addition, outdoor tests proved that the liquid-solid phase change occurred both days, under atmospheric conditions. This ensured that, the day after, the PCM was completely solid and could start a new melting cycle. Further research can optimize this innovative solution, including an extraction system that would allow the PCM to not overheat once fully melted and to exploit, cyclically, the phase change process. This way, the system always works in its best conditions. Future works will be provided in this direction.

Author Contributions: Conceptualization, D.C. and P.P.; Investigation, D.C. and P.P.; Methodology, D.C. and P.P.; Software, D.C.; Validation, D.C. and P.P.; Writing-original draft, D.C.; Writing-review \& editing, P.P. Both authors have read and agreed to the published version of the manuscript. 
Funding: This research received no external funding.

Conflicts of Interest: The authors declare no conflict of interest.

\section{References}

1. Gómez-Uceda, F.J.; Moreno-Garcia, I.M.; Perez-Castañeda, Á.; Fernández-Ahumada, L.M. Study of the dependence of solar radiation regarding design variables in photovoltaic solar installations with optimal dual-axis tracking. Appl. Sci. 2021, 11, 3917. [CrossRef]

2. $\quad$ Saeed, M.A.; Kim, S.H.; Baek, K.; Hyun, J.K.; Lee, S.Y.; Shim, J.W. PEDOT: PSS: CuNW-based transparent composite electrodes for high-performance and flexible organic photovoltaics under indoor lighting. Appl. Surf. Sci. 2021, 567, 150852. [CrossRef]

3. Xu, Y.; Yao, H.; Ma, L.; Wu, Z.; Cui, Y.; Hong, L.; Zu, Y.; Wang, J.; Woo, H.Y.; Hou, J. Organic photovoltaic cells with high efficiencies for both indoor and outdoor applications. Mater. Chem. Front. 2021, 5, 893-900. [CrossRef]

4. Kim, S.H.; Saeed, M.A.; Lee, S.Y.; Shim, J.W. Investigating the indoor performance of planar heterojunction based organic photovoltaics. IEEE J. Photovolt. 2021, 11, 997-1003. [CrossRef]

5. Griffith, J.S.; Rathod, M.S.; Paslaski, J. Some tests of flat plate photovoltaic module cell temperatures in simulated field conditions. In Proceedings of the 15th Photovoltaic Specialists Conference, Kissimmee, FL, USA, 12-15 May 1981; pp. 822-830.

6. Du, D.; Darkwa, J.; Kokogiannakis, G. Thermal management systems for photovoltaics (PV) installations: A critical review. Sol. Energy 2013, 97, 238-254. [CrossRef]

7. Hasanuzzaman, M.; Malek, A.B.M.A.; Islam, M.M.; Pandey, A.K.; Rahim, N.A. Global advancement of cooling technologies for PV systems: A review. Sol. Energy 2016, 137, 25-45. [CrossRef]

8. Shukla, A.; Kant, K.; Sharma, A.; Biwole, P.H. Cooling methodologies of photovoltaic module for enhancing electrical efficiency: A review. Sol. Energy Mater. Sol. Cells 2017, 160, 275-286. [CrossRef]

9. Sathe, T.M.; Dhoble, A.S. A review on recent advancements in photovoltaic thermal techniques. Renew. Sustain. Energy Rev. 2017, 76, 645-672. [CrossRef]

10. Nižetić, S.; Giama, E.; Papadopoulos, A.M. Comprehensive analysis and general economic-environmental evaluation of cooling techniques for photovoltaic panels, part II: Active cooling techniques. Energy Convers. Manag. 2018, 155, 301-323. [CrossRef]

11. Hasan, A.; McCormack, S.J.; Huang, M.J.; Norton, B. Characterization of phase change materials for thermal control of photovoltaics using differential scanning calorimetry and temperature history method. Energy Convers. Manag. 2014, 81, 322-329. [CrossRef]

12. Ma, T.; Li, Z.; Zhao, J. Photovoltaic panel integrated with phase change materials (PV-PCM): Technology overview and materials selection. Renew. Sustain. Energy Rev. 2019, 116, 109406. [CrossRef]

13. Heim, D.; Wieprzkowicz, A.; Knera, D.; Ilomets, S.; Kalamees, T.; Špitalský, Z. Towards improving the durability and overall performance of PV-ETICS by application of a PCM layer. Appl. Sci. 2021, 11, 4667. [CrossRef]

14. Carlucci, F.; Cannavale, A.; Triggiano, A.A.; Squicciarini, A.; Fiorito, F. phase change material integration in building envelopes in different building types and climates: Modeling the benefits of active and passive strategies. Appl. Sci. 2021, 11, 4680. [CrossRef]

15. Abdulmunem, A.R.; Samin, P.M.; Rahman, H.A.; Hussien, H.A.; Mazali, I.I.; Ghazali, H. Numerical and experimental analysis of the tilt angle's effects on the characteristics of the melting process of PCM-based as PV cell's backside heat sink. Renew. Energy 2021, 173, 520-530. [CrossRef]

16. Huang, M.J. The effect of using two PCMs on the thermal regulation performance of BIPV systems. Sol. Energy Mater. Sol. Cells 2011, 95, 957-963. [CrossRef]

17. Sharma, S.; Tahir, A.; Reddy, K.S.; Mallick, T.K. Performance enhancement of a building-integrated concentrating photovoltaic system using phase change material. Sol. Energy Mater. Sol. Cells 2016, 149, 29-39. [CrossRef]

18. Hasan, A.; Sarwar, J.; Alnoman, H.; Abdelbaqi, E.S. Yearly energy performance of a photovoltaic-phase change material (PV-PCM) system in hot climate. Sol. Energy 2017, 146, 417-429. [CrossRef]

19. Ma, T.; Zhao, J.; Li, Z. Mathematical modelling and sensitivity analysis of solar photovoltaic panel integrated with phase change material. Appl. Energy 2018, 228, 1147-1158. [CrossRef]

20. Mahamudul, H.; Rahman, M.; Metselaar, H.S.C.; Mekhilef, S.; Shezan, S.A.; Sohel, R.; Bin Abu Karim, S.; Badiuzaman, W.N.I. Temperature regulation of photovoltaic module using phase change material: A numerical analysis and experimental investigation. Int. J. Photoenergy 2016, 2016, 5917028. [CrossRef]

21. Ho, C.J.; Tanuwijava, A.O.; Lai, C.M. Thermal and electrical performance of a BIPV integrated with a microencapsulated phase change material layer. Energy Build. 2012, 50, 331-338. [CrossRef]

22. Huang, M.J.; Eames, P.C.; Norton, B. Comparison of a small-scale 3D PCM thermal control model with a validated 2D PCM thermal control model. Sol. Energy Mater. Sol. Cells 2006, 90, 1961-1972. [CrossRef]

23. Beemkumar, N.; Karthikeyan, A. Experimental investigation on enhancement of heat transfer in thermal energy storage system using paraffin wax as PCM. Appl. Mech. Mater. 2015, 766, 457-462. [CrossRef]

24. Sarı, A.; Karaipekli, A. Thermal conductivity and latent heat thermal energy storage characteristics of paraffin/expanded graphite composite as phase change material. Appl. Therm. Eng. 2007, 27, 1271-1277. [CrossRef]

25. Wang, Q.; Zhou, D.; Chen, Y.; Eames, P.; Wu, Z. Characterization and effects of thermal cycling on the properties of paraffin/expanded graphite composites. Renew. Energy 2020, 147, 1131-1138. [CrossRef] 
26. Sami, S.; Etesami, N. Improving thermal characteristics and stability of phase change material containing TiO2 nanoparticles after thermal cycles for energy storage. Appl. Therm. Eng. 2017, 124, 346-352. [CrossRef]

27. Harikrishnan, S.; Hussain, S.I.; Devaraju, A.; Sivasamy, P.; Kalaiselvam, S. Improved performance of a newly prepared nanoenhanced phase change material for solar energy storage. J. Mech. Sci. Technol. 2017, 31, 4903-4910. [CrossRef]

28. Cheng, X.; Li, G.; Yu, G.; Li, Y.; Han, J. Effect of expanded graphite and carbon nanotubes on the thermal performance of stearic acid phase change materials. J. Mater. Sci. 2017, 52, 12370-12379. [CrossRef]

29. Babapoor, A.; Karimi, G.; Sabbaghi, S. Thermal characteristic of nanocomposite phase change materials during solidification process. J. Energy Storage 2016, 7, 74-81. [CrossRef]

30. Ahmadi, R.; Monadinia, F.; Maleki, M. Passive/active photovoltaic-thermal (PVT) system implementing infiltrated phase change material (PCM) in PS-CNT foam. Sol. Energy Mater. Sol. Cells 2021, 222, 110942. [CrossRef]

31. Lu, W.; Liu, Z.; Flor, J.F.; Wu, Y.; Yang, M. Investigation on designed fins-enhanced phase change materials system for thermal management of a novel building integrated concentrating PV. Appl. Energy 2018, 225, 696-709. [CrossRef]

32. Khanna, S.; Reddy, K.S.; Mallick, T.K. Optimization of finned solar photovoltaic phase change material (finned pv pcm) system. Int. J. Therm. Sci. 2018, 130, 313-322. [CrossRef]

33. Abdulmunem, A.R.; Jalil, M.J. Indoor investigation and numerical analysis of PV cells temperature regulation using coupled PCM/Fins. Int. J. Heat Technol. 2018, 36, 1212-1222. [CrossRef]

34. Colarossi, D.; Tagliolini, E.; Principi, P.; Fioretti, R. Design and validation of an adjustable large-scale solar simulator. Appl. Sci. 2021, 11, 1964. [CrossRef] 